\title{
Urban Underground Atlas - Horus Project
}

\author{
Stefan Dragos Găitănaru* \\ Groundwater Engineering Research Centre, Technical University of Civil Engineering Bucharest, Romania
}

*Corresponding author: Stefan Dragos Găitănaru, Groundwater Engineering Research Centre, Technical University of Civil Engineering Bucharest, Romania.
Received Date: November 25, 2020

Published Date: November 30, 2020

\begin{abstract}
The urban environment represents a dynamic ecosystem. Most of the economic production for majority of countries is concentrated in the urban areas. The future development is bound to the urban areas capacity to adapt to climate change and social and economic pressures. In the last period more and more scientific and technical papers, projects and committees address the issue of urban climatic resilience and sustainable development. In many cities the demand of space poses significant challenges, as the space needed for developing new functions or relocating and improving existing ones is often not readily available. The understanding of the urban underground represents an ongoing challenge for the scientific community. The Urban Subsurface Atlas it is a new and innovative concept. The innovative aspect of this new atlas comes from the fact that will create a better understanding of the engineering and planning issues under the city. It will be a bridge between the policy makers and the specialists, as it will use the power tools of mapping and 3D visualization.
\end{abstract}

Keywords: Urban underground atlas; Urban subsurface; Urban hydrogeology

\section{Introduction}

In September 2015, the UN General Assembly adopted the 2030 Agenda for Sustainable Development that included 17 Sustainable Development Goals (SDGs). The SDG list cover all the three dimensions of sustainable development [the economic, social and environmental] from no poverty [G1] to clean water and sanitation [G6], and from quality education[G4] to climate action [G13] [1]. The agenda emphasis a holistic approach to achieve a sustainable development for our future world. The urban environment is the most dynamic ecosystem and the sustainability of the future city is central to achieving all 17 SDG, because if current trends continue, by 2050 cities will contain approximately 70 per cent of the world's population and produce 85 per cent of global economic output [2].

Most of the economic production for majority of countries is concentrated in the urban areas. It is clear, just in terms of the population, economic activities, assets, and climate risk they increasingly concentrate, adapting urban areas to climate change requires serious attention [3]. The future development is bound to the urban areas capacity to adapt to climate change and social and economic pressures. Even if is generally accepted that urban climatic resilience represents a critical aspect, in general there is a lack of attention to urban adaptation [3]. Other ecosystems and domains are more notable, like agriculture and forestry. The answer is in many cases easy to be identified: when we speak about climate change, we speak at country level, at ministry level, and therefore there is no ministry for cities. This administrative gap between certain administration levels can create major difficulties in addressing the urban resilience in future projects.

\section{Materials and Methods}

Nevertheless, in the last 10 years more and more scientific and technical papers, projects and committees address the issue of urban climatic resilience and sustainable development. In 2013 the Rockefeller Foundation created the 100 Resilient Cities framework. 
The network is dedicated to helping cities around the world become more resilient to the physical, social and economic challenges that are a growing part of the $21^{\text {st }}$ century [4]. In Europe the URBACT program is aiming to foster sustainable integrated urban development in cities across Europe for more than 15 years [5,6]. More and more innovations and research projects address the urban pattern, the urban physiognomy. From sustainable urban drainage systems (SuDS) to natural based solutions (NBS) and Smart Cities, resources are spent to increase quality of life in our cities. In order to address the global urban challenges of the future, the JPI Urban Europe was created in 2010. This network acts like a research and innovation hub on urban matters [7].

Seen from above, the challenges in a city are easy to be identified: more green and blue surfaces, more space for living areas, less traffic, a functional traffic network, a landscape with an adequate skyline. Lowering the perspective to street view, more issues are reveled: the climatic stress, the pollution, the noise, urban traffic and jams, the smell, the proximity to a park, to a public facility, etc. All these issues are visible or felt, and for that we tend to invest to find answers and solutions to our visible problem. At the end, all these issues came up to one fundamental question: how and where we can expand our city and where do we use our resources more energy efficient? In many cities the demand of space poses significant challenges, as the space needed for developing new functions or relocating and improving existing ones is often not readily available [8]. Urban areas can function more efficiently using multipurpose underground space to alleviate the pressure on the surface [6].

The main challenge when we refer to the underground space in an urban environment comes from the extreme complexity of natural components (soil, rock, groundwater) and anthropogenic elements (tunnels, foundations, water, and wastewater infrastructure, etc.). Like a puzzle, the subsurface of our cities is difficult to assess and, in many cases, to model in such a manner that can be easily used as an urban planning resource.

From the scientific point of view, the understanding of the urban underground represents an ongoing challenge for the scientific community. At international level, the scientific community gathered around important projects and professional organizations involved in the urban underground research. One of the most dynamic organization is the ACUUS (Associated research Centres for Urban Underground Space) a non-governmental organization dedicated to partnerships amongst experts who design, analyse and decide upon the use of our cities underground spaces [9]. Even if in the international scientific community, the issue is more and more interesting and tempting [10-13] there are still gaps between the planners, the engineers and the local authorities.

The European COST Action TU1206 SUB-URBAN - A European network to improve understanding and use of the ground beneath our cities, gathered scientists and underground specialists from 31 countries in order to find practical solutions to bridge the gap between the engineers, scientist, urban planners and stakeholders. Romania was represented by CCIAS-UTCB in this framework. The outcomes of this project underlined the clear necessity and the continuous challenge pose by the underground environment in the urban areas. Urban underground planning issues and challenges are the focus of the papers respectively by Besner [14], and Gonzalez et al. [15]. Good practice in other disciplines is identified in papers addressing: 3D urban geochemistry for contamination studies etc., as opposed to prevailing 2D urban surveys and strategies; and the impacts caused by the plethora of urban subsurface development on cultural heritage, varying from individual projects to cumulative and city-scales [16]. One of the most advanced research in the field of urban subsurface science, engineering and planning is carried out by the Geological Survey of Finland together with Helsinki Municipality. Since 2010, Helsinki City Council approved the underground master plan [17].

In Romania, the scientific domain it is still in the early stages. Beside the sustained efforts of CCIAS during the last 9 years, efforts accomplished by hosting the Cost SUB-Urban final conference in Bucharest and publishing a special issue of Procedia Engineering for the outcomes of this project, and also the GEO-Atlas of Bucharest [18], there is no clear scientific path for this research areas. Most of the urban scientist (urban planning, urban geography, urban geology, urban hydrogeology, cultural heritage, urban engineers, geotechnical engineers) are focusing on their domain without considering the bigger picture.

There is no magical recipe addressing the urban subsurface management and planning, all the involved actors, specialists and researchers are in many cases limited by their own experience and know-how and tend to exaggerate and to point out certain aspects (geothermal potential, groundwater infrastructure interaction, water and ground pollution, geotechnical zoning, etc) and this represents the major limitation and drawback. Overpassing this limitation represents the main challenge of HORUS project.

\section{Results and Discussion}

The HORUS project is based on the experience of previous projects, were pieces of our urban underground space were analysed and assessed. An important role for the development of this project is represented by the Bucharest experience (since 2010 www.simpa.utcb.ro, [16,19-21]), COST TU1206 (http://sub-urban. squarespace.com/) and INXCES (https://inxces.eu/). The project implementation will start from the findings of all the previous projects and will try to assemble all the research results in a new holistic manner that can be easily translated to the urban planners and stakeholders. Nevertheless, the approach is focused on the new scientific paradigm of multidisciplinary and applied innovation.

The main objective [MO] is represented by the development of a new holistic method to map the underground Space for a future Urban climatic Resilience. Reaching this objective is translated by 
the Urban Subsurface Atlas. All the secondary objectives, activities, deliverables, and milestones will contribute step by step in achieving the main goal of the project. Beside the main objective a series of secondary objectives arose from HORUS proposal. These secondary objectives can be summarized as follows: [SO1] Development of an integrated and holistic urban subsurface database; [SO2] Identifying the gaps between the policy makers, urban planners, engineers and scientist regarding the urban underground space plan- ning; [SO3] Increase the know-how of the underground space for 3 major cities in Romania; [SO4] Develop an interactive web-based urban subsurface atlas to address the local community, scientists, urban planners and engineers (Figure 1).

The project will target 3 cities in Romania: Bucuresti, Brasov and Ramnicu Valcea (Figures 1 \& 2).

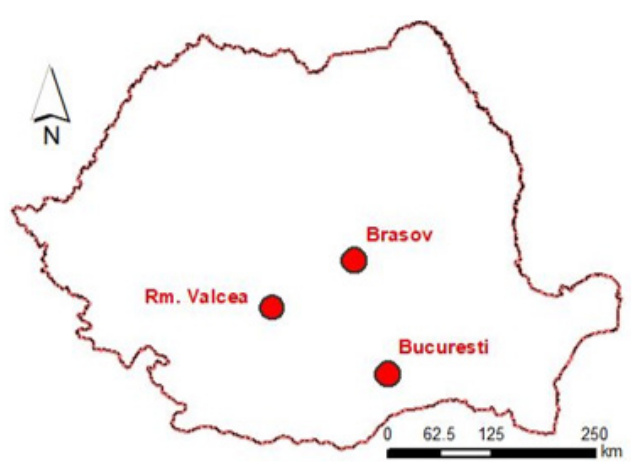

Figure 1: Location of the project study sites.

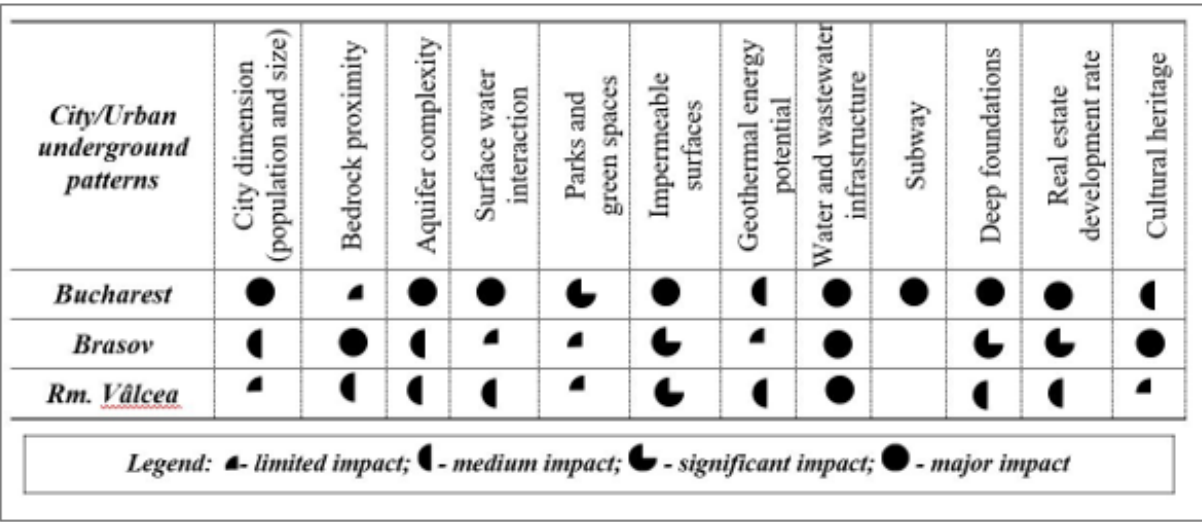

Figure 2: Urban underground patterns impact upon the urban planning and development.

- Bucharest is the capital of Romania and the biggest city (1.94 mil inhabitants) in Romania. Located in the south part of Romania, close to the river Danube (around $64 \mathrm{~km}$ ), the city expands on $228 \mathrm{~km}^{2}$ and it is divided into 6 districts [22]. The geology and hydrogeology are typical to a plain city, located on recent deposits (Quaternary) and a complex aquifer system (3 major aquifer systems). The urban pattern is complex, with constructed surfaces, an underground maze of infrastructure (water, wastewater, subway, tunnels, foundations, etc.) and important surface water bodies and parks.

- Brașov is one of the biggest cities in Transilvania, with a population over 250.000 inhabitants. Even if the administrative limits of Brasov also include the surrounding communities (and the Poiana Brasov sky resort), we will try to address to the typical urban area. From the point of view of geology, the bedrock is near the surface in many of the urban areas, the rest of the city lays on a torrential alluvial cone (Quaternary). Brasov is a very interesting city due to its unique cultural heritage buildings.

- $\quad \mathbf{R m}$.Vâlcea is the capital of Vâlcea county situated on the Olt riverbanks south of the Carpathians. Comparing with $\mathrm{Bu}$ charest and Brasov is a small city with a population around 100.000 inhabitants. The geological settings are represented by recent alluvial deposits (the city is located on the flood plain and terrenes of Olt river). In the last years even if the industry has declined the city expansion is more and more visible (a new a shopping centre and a new neighborhood located in the flood plain of Olt river) (Figure 2). 


\section{Conclusion}

The general workflow of the project follows a step by step procedure, from the conceptual data framework of the urban underground space, to data acquisition of supplementary data, to methodology development and case study examples with direct calibration and validation.

The Urban Subsurface Atlas it is a new and innovative concept. In the science world the concept of an urban atlas it is not new (Urban Atlas - Copernicus EU framework [23]), and also the underground space atlas has already been in place since 2014 - The Underground Atlas Project [24]. Also, several efforts regarding urban planning, natural based solutions and climatic adaptation were developed in the last years [25], in one of this project the project leader and the mentor have been involved (www.inxces.eu). At national level, the Geoatlasul Bucuresti [18] and the Atlas de la Roumanie [26] represents a good starting point for the development of a new holistic method to map the urban underground space. The innovative aspect of this new atlas comes from the fact that will create a better understanding of the engineering and planning issues under the city. It will be a bridge between the policy makers and the specialists, as it will use the power tools of mapping and 3D visualization. All the efforts mentioned before stopped somehow at a general level, only discrete information, or only addressing the surface and visible aspects.

\section{Acknowledgement}

This work was supported by a grant of the Romanian Ministry of Education and Research, CNCS - UEFISCDI, project number PNIII-P1-1.1-PD-2019-0484, within PNCDI III.

\section{Conflict of Interest}

No conflict of interest.

\section{References}

1. (2015) UN DESA. Department of Economic and Social Affairs Disability.

2. Independent Group of Scientists appointed by the Secretary-General (2019) THE FUTURE IS NOW - SCIENCE FOR ACHIEVING SUSTAINABLE DEVELOPMENT. United Nations, New York.

3. A Revi, S DE, AD F, CM J, K RBR, et al. (2014) Urban areas. In: Climate Change 2014: Impacts, Adaptation, and Vulnerability. Part A: Global and Sectoral Aspects. Contribution of Working Group II to the Fifth Assessment Report of the Intergovernmental Panel on Climate Change. Cambridge University Press, Cambridge.

4. 100 Resilient Cities. http://www.100resilientcities.org/.

5. URBACT. https://urbact.eu/.

6. Y Bai (2019) Underground Engineering - Planning, Design, Construction and Operation of the Underground Space, London: Academic Press.
7. JPI Urban Europe. https://jpi-urbaneurope.eu/about/intro/.

8. W Broere (2016). Urban underground space: Solving the problems of today's cities. Tunnelling and Underground Space Technology 55: 245248.

9. ACUUS. https://www.acuus.org/.

10. H Will (2019) Underground: A Human History of the Worlds Beneath Our Feet, Spiegel \& Grau.

11. A Han, C Antonia (2018) Underground Spaces Unveiled: Planning and creating the cities of the future, ICE Publishing.

12. D Perrault (2016) Groundscapes - Other Topographies, Editions HYX.

13. DM EFJ, H HRGK, VR CCDF (2012) Sustainable Development and Management of the Shallow Subsurface, London: Geological Society of London.

14. B Jacques (2018) Public Hearing For Underground Space Development: The Canadian Experience. in 16th World Conference Of the Associated Research Centers for the Urban Underground Space Integrated Underground Solutions for Compact Metropolitan Cities, Hong Kong, 2018.

15. G Rubén, C Lois, U Beatriz Moar, O Miguel Pazos (2017) The underground of European cities in planning documents: the case of A Coruña (Spain). Precedia Engineering 209: 42-48.

16. G Constantin Radu, C Diarmad, B Johannes de (2017) PREFACE: The Urban Subsurface - from Geoscience and Engineering to Spatial Planning and Management. Procedia Engineering 209: 1-224.

17. I Vähäaho (2018) Urban Underground Space - Sustainable Property Development in Helsinki, Helsinki: Urban Environment Publications.

18. L R, A N, P M, E P (2008) Geo-atlasul municipiului București, Bucharest.

19. D Gaitanaru, C Gogu, M Boukhemacha, L Litescu, V Zaharia, A Moldovan, et al. (2017) Bucharest city urban groundwater monitoring system. Procedia Engineering 209: 143-147.

20. M Boukhemacha, C Gogu, I Serpescu, D Gaitanaru, I Bica (2015) A hydrogeological conceptual approach to study urban groundwater flow in Bucharest city. Hydrogeology Journal 23(3): 437-450.

21. C Gogu, M Boukhemacha, D Găitănaru, I Moraru (2018) Interaction Between City Subsurface Infrastructure and Groundwater. in New Trends in Urban Drainage Modelling, Springer, Green Energy and Technology.

22. PM Bucuresti, "PMB.RO”. http://www.pmb.ro/.

23. E Europe "Urban Atlas." https://www.eea.europa.eu/data-and-maps/ data/urban-atlas.

24. D Kaliampakos, A Benardos, A Mavrikos, G Panagiotopoulos (2016) The Underground Atlas Project. Tunnelling and Underground Space? Technology 55: 229-235.

25. F Boogaard, O Jonas, T Muthanna, R Heikoop, G Venvik (2019) International knowledge exchange on climate adaptation with the Climatescan platform. in 4th European Climate Change Adaptation conference, Lisbon.

26. R Violette, I Ioan, P Maria, G Octavian (2006) Atlasul Romaniei, Bucharest: RAO. 